CLINICAL STUDY

\title{
Endocrine and metabolic responses to extreme altitude and physical exercise in climbers
}

\author{
Andrea Benso, Fabio Broglio, Gianluca Aimaretti, Barbara Lucatello, Fabio Lanfranco, Ezio Ghigo and \\ Silvia Grottoli \\ Division of Endocrinology and Metabolism, Department of Internal Medicine, Molinette Hospital, University of Turin, Corso Dogliotti 14, \\ 10126 Turin, Italy \\ (Correspondence should be addressed to S Grottoli; Email: ninagro@yahoo.it)
}

\begin{abstract}
Context: Chronic hypoxia induces complex metabolic and endocrine adaptations. High-altitude (HA) exposure is a physiological model of hypoxia.

Objective: To further investigate the endocrine and metabolic responses to extreme HA.

Methods: We studied nine male elite climbers at sea level and at $5200 \mathrm{~m}$ after climbing Mt. Everest. Results: After 7 weeks at HA, body weight was reduced $(P<0.05)$; regarding endocrine variables we observed: a) an increase of 2 -h mean GH concentration $(P<0.05)$ as well as of total IGF-I and IGF binding protein-3 levels $(P<0.05$ for both); b) a prolactin increase $(P<0.05)$ coupled with testosterone decrease $(P<0.01)$ and progesterone increase $(P<0.05)$ without any change in estradiol levels: c) no change in cortisol, ACTH, and dehydroepiandrosterone sulfate (DHEAS) levels; d) an increase in free thyroxine $(P<0.05)$ and free tri-iodothyronine $\left(\mathrm{T}_{3}\right)$ decrease $(P<0.05)$ but no change in TSH levels; e) a plasma glucose decrease $(P<0.05)$ without any change in insulin levels; $f$ ) an increase in mean free fatty acid levels $(P<0.05) ; \mathrm{g})$ despite body weight loss, leptin levels showed non-significant trend toward decrease, while ghrelin levels did not change at all.

Conclusions: The results of the present study in a unique experimental human model of maximal exposure to altitude and physical exercise demonstrate that extreme HA and strenuous physical exercise are coupled with specific endocrine adaptations. These include increased activity of the $\mathrm{GH} / \mathrm{IGF}-\mathrm{I}$ axis and a low $\mathrm{T}_{3}$ syndrome but no change in ghrelin and leptin that was expected taking into account body weight decrease. These findings would contribute to better understanding human endocrine and metabolic physiology in hypoxic conditions.
\end{abstract}

European Journal of Endocrinology 157 733-740

\section{Introduction}

The adaptive processes to hypoxia imply complex modifications in the homeostatic steady state of several endocrine and metabolic functions (1). Apart from clinical conditions characterized by low oxygen availability (such as obstructive sleep apnea syndrome and cardiopathy), a widely studied model of hypoxia is represented by the high-altitude (HA) hypoxia. In fact, the reduced availability of oxygen owing to low barometric pressure is the basic problem associated with HA. The acute exposure to reduced partial pressure of oxygen at HA decreases arterial oxygen saturation, stimulates the sympathoadrenal system, and provokes shifts in substrate metabolism (2-5). Indeed, the response to HA in terms of energy utilization has been deeply investigated $(2,6-11)$ but data about endocrine adaptations are scanty and discrepant, likely reflecting different experimental models and wide relative ranges of altitudes, and generally investigating the short-term endocrine response only.
An increase in thyroid hormones explained as a response to the hypoxic stress $(12,13)$ or, alternatively, as a function of altered regulation of thyrotrophin (TSH) secretion has been originally reported (14). On the other hand, other authors have reported HA-induced increase in progesterone levels but no change in pituitary, gonadal, and adrenal hormones in subjects who had a prolonged stay at HA but were not performing any physical activity (15). Conflicting with this study, other data reported that a prolonged exposure to HA was coupled with an increase in prolactin but decrease in luteinizing hormone and testosterone levels (16). There is no knowledge about the response of the growth hormone $(\mathrm{GH})$ /insulin-like growth factor-I (IGF-I) axis to extreme HA, while more is known about the metabolic adaptations.

Some studies investigated glucose and lipid metabolism at HA in detail. In particular, physical exercise at $4300 \mathrm{~m}$ after prolonged acclimatization greatly increased dependence on blood glucose as a fuel and on insulin action (2) but decreased reliance on lipid 
substrate (7). A transition from a state of reduced to increased insulin sensitivity during the progressive course of acclimatization to HA hypoxia in men has also been reported by other authors (9).

More recently, the emerging role of leptin and ghrelin in the regulation of energy balance prompted an evaluation of leptin response to HA (17-20). Subjects exposed to HA lose significant amounts of body mass from fat mass as well as fat-free mass, particularly if involved in physical performance such as climbing $(10,11)$. As a consequence there is an energy imbalance, likely reflecting increased energy expenditure and decreased, or at least inadequate, food intake probably due to hypoxia-related satiety (10, 11). In this context, significant variations in leptin and ghrelin secretion were expected but the data available so far are discrepant. Leptin levels have been reported as either increased $(17,19)$, decreased $(18)$, or unchanged (20), while a trend towards decreased ghrelin levels has been reported at HA (19).

Based on the foregoing, we aimed to further investigate the endocrine and metabolic responses to prolonged exposure to extreme HA hypobaric hypoxia, in association with physical exercise, as that performed by elite climbers.

\section{Subjects and methods}

This study was part of a larger scientific project organized by 'Ev-K2-CNR' Committee and by the Italian National Institute of Mountain (IMONT) during the celebration of the 50th anniversary of the K2 Italian climb in 1954.

Nine male well-trained elite climbers (age (mean \pm S.E.м.): $40.2 \pm 1.4$ years) of the Italian expedition ' $\mathrm{K} 2$ 200450 years later' to the north face of Mt. Everest were studied; none of them had a significant medical history. All of them gave written informed consent to participate in the study which had been previously approved by the Ethical Committee of the University of Turin.

All climbers had previous experience of climbing in the Himalayas and spent 2 months at an altitude no lower than $5200 \mathrm{~m}$ of the base camp (BC), with a stepby-step acclimatization program.

Five of the climbers reached the summit at $8852 \mathrm{~m}$ (21), three of them reached an altitude of $8600 \mathrm{~m}$ and one an altitude of $7500 \mathrm{~m}$. None used oxygen supplementation in the 2 months at HA.

All the subjects studied underwent the following hormonal and metabolic evaluations at sea level one month before the expedition and immediately after their return to the $\mathrm{BC}$ following the attempt of ascending Mt. Everest: a) spontaneous $\mathrm{GH}$, ghrelin, and leptin secretion (sampling every $30 \mathrm{~min}$ for $2 \mathrm{~h}$ ); b) single measurements of IGF-I, IGF binding protein-3, prolactin, adrenocorticotrophin (ACTH), cortisol, DHEAS, free tri-iodothyronine $\left(\mathrm{fT}_{3}\right)$, free thyroxine $\left(\mathrm{fT}_{4}\right), \mathrm{TSH}$, testosterone, estradiol, progesterone, glucose, insulin, and free fatty acids (FFA) levels.

After overnight fasting, blood samples were taken in the morning at $0700-0730 \mathrm{~h}, 30 \mathrm{~min}$ after an indwelling catheter had been placed into an antecubital vein of the forearm kept patent by slow infusion of isotonic saline.

Climbers had free access to palatable foods and their diet was balanced in carbohydrate $(\sim 58 \%)$, lipid $(\sim 30 \%)$, and protein $(\sim 12 \%)$ contents.

Blood samples were appropriately treated and stored, and biochemical variables were then all measured in duplicate by the following methods:

Serum GH levels $(\mathrm{ng} / \mathrm{ml})$ were measured by IRMA (hGH IRMA CT, RADIM SpA, Pomezia, Roma, Italy). The sensitivity of the assay was $0.15 \mathrm{ng} / \mathrm{ml}$. The interand intra-assay coefficients of variation were 3.7 and $3.2 \%$ respectively.

Plasma total ghrelin levels $(\mathrm{pg} / \mathrm{ml})$ were measured for immunoreactive ghrelin concentration by a commercially available RIA (Phoenix Pharmaceuticals, Mountain View, CA, USA). The inter- and intra-assay coefficients of variation were 13.6 and $5.3 \%$ respectively.

Serum IGF-I levels $(1 \mathrm{ng} / \mathrm{ml}=0.131 \mathrm{nmol} / \mathrm{l})$ were measured by RIA (SM-C-RIA-CT, Pantec, Torino, Italy). The sensitivity of the assay was $0.25 \mathrm{ng} / \mathrm{ml}$. The interand intra-assay coefficients of variation were 9.8 and $7.3 \%$ respectively.

Serum IGFBP-3 levels (ng/ml) were measured by IRMA (IRMA IGFBP-3, Immunotech, Marsiglia, Francia). The sensitivity of the assay was $50 \mathrm{ng} / \mathrm{ml}$. The inter- and intraassay coefficients of variation were 9.5 and $6.0 \%$ respectively.

Serum prolactin levels $(\mathrm{ng} / \mathrm{ml}=\mu \mathrm{g} / \mathrm{l})$ were measured by IRMA (PRL IRMA, Immunotech distr. PANTEC). The sensitivity of the assay was $0.5 \mathrm{ng} / \mathrm{ml}$. The inter- and intra-assay coefficients of variation were 8.0 and $2.8 \%$ respectively.

Serum testosterone levels $(1 \mathrm{ng} / \mathrm{ml}=3.47 \mathrm{nmol} / \mathrm{l})$ were measured by RIA (Testosterone, ICN Pharmaceuticals inc. MP Biomedicals, Costa Mesa, CA, USA). The inter- and intra-assay coefficients of variation were 11.3 and $11.0 \%$ respectively.

Serum estradiol levels $(1 \mathrm{pg} / \mathrm{ml}=3.67 \mathrm{pmol} / \mathrm{l})$ were measured by RIA (ESTRADIOL RIA, DSL, Webster, TX, USA). The sensitivity of the assay was $2.2 \mathrm{pg} / \mathrm{ml}$. The inter- and intra-assay coefficients of variation were 9.9 and $7.7 \%$ respectively.

Serum progesterone levels $(1 \mathrm{ng} / \mathrm{ml}=3.18 \mathrm{nmol} / \mathrm{l})$ were measured by IRMA (PROGESTERONE CT, RADIM $\mathrm{SpA}$ ). The sensitivity of the assay was $0.12 \mathrm{ng} / \mathrm{ml}$. The inter- and intra-assay coefficients of variation were 12.1 and $8.9 \%$ respectively.

Plasma ACTH levels $(1 \mathrm{pg} / \mathrm{ml}=0.22 \mathrm{pmol} / \mathrm{l})$ were measured by IRMA (ACTH, Nichols Institute Diagnostic, San Juan Capistrano, CA, USA). The sensitivity of the assay was $1 \mathrm{pg} / \mathrm{ml}$. The ranges of inter- and intra-assay coefficients of variation were 6.9 and $5.5 \%$ respectively. 
Serum cortisol levels $(1 \mathrm{ng} / \mathrm{ml}=27.59 \mathrm{nmol} / \mathrm{l})$ were measured by RIA (RIA CORTISOLO, IMMUNOTECH distrib. PANTEC). The sensitivity of the assay was $10 \mathrm{nM}$. The inter- and intra-assay coefficients of variation were 7.3 and $4.3 \%$ respectively.

Serum DHEAS levels $(1 \mu \mathrm{g} / \mathrm{dl}=0.2714 \mu \mathrm{mol} / \mathrm{l})$ were measured by RIA (DHEA-S CT, RADIM SpA). The sensitivity of the assay was $2 \mu \mathrm{g} / \mathrm{dl}$. The inter- and intra-assay coefficients of variation were 8.5 and $7.3 \%$ respectively.

Serum insulin levels $(1 \mu \mathrm{U} / \mathrm{ml}=7.175 \mathrm{pmol} / \mathrm{l})$ were measured by IRMA (INSIK-5, DIASORIN, Saluggia, Italy). The sensitivity of the insulin assay was $4 \mu \mathrm{U} / \mathrm{ml}$. The coefficient of variation was $6.1 \%$ for both inter- and intra-assays.

Plasma glucose levels $(1 \mathrm{mg} / \mathrm{dl}=0.05556 \mathrm{mmol} / \mathrm{l})$ were measured by a gluco-oxidase colorimetric method (Glucofix, by Menarini Diagnostici, Florence, Italy).

Serum leptin levels $(\mathrm{ng} / \mathrm{ml})$ were measured by RIA (HUMAN-LEPTIN-RIA-SENSITIVE, MEDIAGNOST, Reutlingen, Germany). The sensitivity of the assay was $0.04 \mathrm{ng} / \mathrm{ml}$. The inter- and intra-assay coefficients of variation were 7.6 and $5.0 \%$ respectively.

Serum free fatty acids levels $(\mathrm{mEq} / \mathrm{l})$ were measured by an enzymatic colorimetric method (NEFA C, WAKO Chemicals GmbH, Neuss, Germany). The sensitivity of the assay was $1 \mathrm{mEq} / \mathrm{l}$. The inter- and intra-assay coefficients of variation were 4.1 and $1.1 \%$ respectively.

Serum $\mathrm{fT}_{3}$ levels (pmol/l) were measured by RIA (Kit pbr-system RIA, Bouty Laboratories, Milan, Italy). The sensitivity of the assay was $0.76 \mathrm{pmol} / \mathrm{l}$. The inter- and intra-assay coefficients of variation were 6.3 and $3.9 \%$ respectively.

Serum $\mathrm{fT}_{4}$ levels (pmol/l) were measured by RIA (Kit pbr-system RIA, Bouty). The sensitivity of the assay was $0.38 \mathrm{pmol} / \mathrm{l}$. The inter- and intra-assay coefficients of variation were 6.6 and $3.8 \%$ respectively.

Serum TSH levels $(\mathrm{mU} / \mathrm{l})$ were measured by IRMA (TSH-CTK-3, SORIN Biomedica, Saluggia, Italy). The sensitivity of the assay was $0.04 \mathrm{mU} / \mathrm{l}$. The inter- and intra-assay coefficients of variation were 8.0 and $3.3 \%$ respectively.

Biochemical variables are expressed as mean \pm s.E.M. of absolute values and also of areas under curves (AUC) calculated by trapezoidal integration. Statistical analysis was carried out using non-parametric Mann-Whitney test.

\section{Results}

None of the climbers developed severe altitude sickness or HA edema.

Over the period of 2 months at HA, we observed an average weight loss of $5 \mathrm{~kg}$ (weight at HA: $66.1 \pm 2.2 \mathrm{~kg}$, weight at sea level: $71.1 \pm 1.9 \mathrm{~kg}, P<0.05$; Table 1 ).

With respect to values recorded at sea level, endocrine and metabolic variables were modified or unchanged by HA (Table 1).
Mean GH concentration (over $2 \mathrm{~h}$ ) increased (AUC (mean \pm s.E.M.): $755.6 \pm 110.4$ vs $284.2 \pm 104.8 \mu \mathrm{g} / \mathrm{l} \mathrm{min}$; $P<0.01)$. This change in GH status was coupled with a concomitant increase $(P<0.05)$ in mean total IGF-I $(219.6 \pm 31.1$ vs $167.5 \pm 22.7 \mu \mathrm{g} / \mathrm{l})$ and IGFBP-3 (3.7 \pm 0.3 vs $2.9 \pm 0.2 \mu \mathrm{g} / \mathrm{ml}$; Fig. 1$)$.

Prolactin levels increased $(7.8 \pm 0.8$ vs $6.0 \pm 0.6 \mu \mathrm{g} / \mathrm{l}$; $P<0.05)$, whereas testosterone levels decreased $(3.6 \pm$ 0.4 vs $5.5 \pm 0.6 \mathrm{ng} / \mathrm{ml}, P<0.01)$. These changes were associated with a concomitant increase in progesterone $(1.8 \pm 0.1$ vs $1.4 \pm 0.1 \mathrm{ng} / \mathrm{ml} ; P<0.05)$. Despite these significant changes, these variables at HA persisted within the normal range. No change in estradiol levels was recorded (Fig. 2).

Cortisol, ACTH, and DHEAS levels did not change.

Although TSH levels were not modified, $\mathrm{fT}_{4}$ levels increased $(13.7 \pm 0.7$ vs $10.4 \pm 0.6 \mathrm{ng} / \mathrm{l} ; P<0.05)$ while free $\mathrm{T}_{3}$ levels decreased $(2.0 \pm 0.1$ vs $2.7 \pm$ $0.1 \mathrm{ng} / \mathrm{l} ; \mathrm{P}<0.05)$; $\mathrm{fT}_{3}$ levels at HA were below the normal range of our laboratory (Fig. 3 ).

After maximal physical exercise at HA, morning plasma glucose levels were significantly reduced $(70.1 \pm 3.7$ vs $80.0 \pm 2.6 \mathrm{mg} / \mathrm{dl} ; P<0.05)$ without any significant change in insulin levels $(10.9 \pm 0.8$ vs $10.1 \pm 0.8 \mathrm{mU} / \mathrm{l})$. However, over the 2 -h evaluation, there was no significant change in the two variables, though insulin showed a trend toward decrease (glucose AUC: $9051.7 .0 \pm 316.8$ vs $9671.7 \pm 365.1 \mathrm{mg} / \mathrm{dl} \mathrm{min}$; insulin AUC: $1117.0 \pm 59.2$ vs $1460.3 \pm$ $80.1 \mathrm{mU} / \mathrm{l} \mathrm{min).}$

Mean FFA levels after maximal physical exercise at HA increased $(0.53 \pm 0.11$ vs $0.36 \pm 0.05 \mathrm{mEq} / \mathrm{l})$.

Despite the decrease in body weight after the performance at HA, 2-h mean leptin secretion showed a trend toward decrease $(60.1 \pm 3.6$ vs $90.5 \pm 7.2 \mathrm{ng} / \mathrm{ml} \mathrm{min}$, p: $\mathrm{ns})$, while ghrelin levels did not change (18 312.5 \pm 1934.5 vs $17996.8 \pm 1237.0$ pg/ml min, p: ns; Fig. 4).

\section{Discussion}

The results of the present study in a unique experimental human model of maximal exposure to altitude and physical exercise demonstrate that extreme HA and strenuous physical exercise are coupled with specific endocrine adaptations. Particularly, these include increased activity of the GH/IGF-I axis and a low $\mathrm{T}_{3}$ syndrome but no significant change in ghrelin and leptin although some could have been expected, taking into account the decrease in body weight. On the other hand, the effects of extreme physical performance at HA also included: (i) some increase in prolactin and progesterone but decrease in testosterone levels; (ii) no change in the variables exploring the function of hypothalamus-pituitary-adrenal axis; and (iii) some expected changes in glucose and lipid metabolism.

The Italian expedition 'K2-2004 50 years later' to Mt. Everest represented the opportunity to further 
Table 1 Individual climber anthropometric, hormonal, and metabolic values.

\begin{tabular}{|c|c|c|c|c|c|c|c|c|c|c|c|c|c|c|c|c|c|c|c|c|c|c|}
\hline & \multirow[b]{2}{*}{$\begin{array}{l}\text { Height } \\
(\mathrm{cm})\end{array}$} & \multicolumn{2}{|c|}{$\begin{array}{l}\text { Weight } \\
\text { (kg) }\end{array}$} & \multicolumn{2}{|c|}{ BMI $\left(\mathrm{kg} / \mathrm{cm}^{2}\right)$} & \multicolumn{2}{|c|}{$\begin{array}{l}\text { GH AUC } \\
(\mu \mathrm{g} / / \mathrm{Imin})\end{array}$} & \multicolumn{2}{|c|}{$\begin{array}{l}\text { IGF-I } \\
(\mu \mathrm{g} / \mathrm{I})\end{array}$} & \multicolumn{2}{|c|}{$\begin{array}{c}\text { IGFBP-3 } \\
(\mu \mathrm{g} / \mathrm{ml})\end{array}$} & \multicolumn{2}{|c|}{$\begin{array}{l}\text { PRL } \\
(\mu \mathrm{g} / \mathrm{l})\end{array}$} & $\begin{array}{c}\mathbf{T} \\
(\mathrm{ng} / \mathrm{ml})\end{array}$ & \multicolumn{2}{|c|}{$\underset{(\mathrm{ng} / \mathrm{ml})}{\mathbf{P G}}$} & \multicolumn{2}{|c|}{$\underset{(\mathrm{pg} / \mathrm{ml})}{\mathbf{E}_{2}}$} & \multicolumn{2}{|c|}{$\begin{array}{l}\text { Cortisol } \\
(\mathrm{ng} / \mathrm{ml})\end{array}$} & \multicolumn{2}{|c|}{$\begin{array}{l}\text { ACTH } \\
(\mathrm{pg} / \mathrm{ml})\end{array}$} \\
\hline & & SL & $B C$ & SL & $B C$ & SL & $B C$ & SL & $\mathrm{BC}$ & SL & $B C$ & SL & $B C$ & SL & SL & BC & SL & $B C$ & SL & $\mathrm{BC}$ & SL & $B C$ \\
\hline Climber 1 & 1.77 & 67 & 57 & 21.4 & 18.2 & 385.5 & 707.0 & 132.0 & 153.0 & 2.2 & 3.4 & 4.3 & 0.1 & 3.9 & 1.6 & 2.2 & 18.0 & 16.7 & 228.6 & 273.9 & 11.0 & 35.0 \\
\hline & & 67 & 62 & 23.2 & 21.5 & 123.0 & 200.1 & 107.0 & 167. & 2.6 & 3.0 & & 6.7 & 6.2 & 1. & & 17.7 & 16.5 & 83.7 & 190.0 & 32.0 & 23.0 \\
\hline Climber 3 & 1.78 & 69 & 66 & 21.8 & 20.8 & 115.5 & 946.5 & 213.4 & 350.0 & 3.2 & 4.8 & 5.8 & 9.4 & 5.7 & 1.4 & 2.3 & 14.7 & 16.5 & 134.7 & 184.1 & 13.0 & 16.0 \\
\hline Climber 4 & & 73 & 67 & 23.6 & 21.6 & 388.5 & 621.0 & 163.0 & 147.0 & 3.3 & 3.4 & & 5.7 & 3.2 & 1.5 & & 14.9 & 16.4 & 265.6 & 212.1 & 46.0 & 29.0 \\
\hline limber 5 & 1.80 & 80 & 76 & 24.7 & 23.5 & 262.5 & 898.5 & 213.0 & 245. & 3.3 & 4.1 & 4.9 & 5.8 & 5.9 & 1. & 1 & 22.0 & 10.6 & 178.7 & 171.7 & 15.0 & 13.0 \\
\hline Clim & & 72 & 69 & 21.7 & 20.8 & 274.5 & 375.0 & 59.0 & 99 & 1.8 & 1.9 & 9.1 & 1.9 & 6.4 & 2.0 & 2. & 13 & 12.5 & 215.9 & & 27.0 & 26.0 \\
\hline & 1.80 & 75 & 70 & 23.1 & 21.6 & 1.5 & 1057.5 & 217.0 & 232.0 & 3.3 & 3.9 & 7.0 & 7.1 & 4.7 & 1.3 & 1.4 & 11.5 & 11.0 & 204.3 & 215.2 & 28.0 & 19.0 \\
\hline & & 75 & 70 & 22.9 & 21.4 & 978.0 & 1141.5 & 262.0 & 349 & 3.3 & 4.7 & 5.5 & 6.8 & 4.7 & 1. & 1. & 21 & 25.2 & & & 18.0 & 14.0 \\
\hline \multirow[t]{3}{*}{ Climber 9} & 1. & 62 & 58 & 22.0 & 20.5 & 28.5 & 853.5 & 141.0 & 234.0 & 3.2 & 4.5 & 4.4 & 6.4 & 9.1 & 1. & 2.3 & 21.6 & 15.5 & 229.3 & 241.8 & 38.0 & 34.0 \\
\hline & \multicolumn{2}{|c|}{$\begin{array}{l}\text { TSH } \\
(\mathrm{ng} / \mathrm{l})\end{array}$} & \multicolumn{3}{|c|}{$\begin{array}{l}\mathrm{fT}_{3} \\
(\mathrm{ng} / \mathrm{l})\end{array}$} & \multicolumn{2}{|c|}{$\begin{array}{l}\mathrm{fT}_{4} \\
(\mathrm{ng} / \mathrm{l})\end{array}$} & \multicolumn{2}{|c|}{$\begin{array}{l}\text { Glucose } \\
\text { (mg/dl) }\end{array}$} & \multicolumn{2}{|c|}{$\begin{array}{c}\text { Glucose AUC } \\
\text { (mg/dl min) }\end{array}$} & \multicolumn{2}{|c|}{$\begin{array}{c}\text { Insulin } \\
(\mathrm{mU} / \mathrm{l})\end{array}$} & \multicolumn{2}{|c|}{$\begin{array}{c}\text { Insulin AUC } \\
(\mathrm{mU} / \mathrm{min})\end{array}$} & \multicolumn{2}{|c|}{$\begin{array}{c}\text { FFA } \\
(\mathrm{mEq} / \mathrm{l})\end{array}$} & \multicolumn{2}{|c|}{$\begin{array}{c}\text { Leptin AUC } \\
\text { (ng/ml min) }\end{array}$} & \multicolumn{3}{|c|}{$\begin{array}{c}\text { Ghrelin AUC } \\
\text { (pg/ml min) }\end{array}$} \\
\hline & SL & $\mathrm{BC}$ & SL & $R$ & & SL & $B C$ & SL & $\mathrm{BC}$ & SL & $\mathrm{BC}$ & SL & $\mathrm{BC}$ & SL & $\mathrm{BC}$ & SL & $B C$ & SL & $\mathrm{BC}$ & SL & & $\mathrm{BC}$ \\
\hline & & & & & & 11.1 & 16.0 & 81.0 & 55 & 955 & 778 & 13 & 8.5 & 1302.0 & 1006.5 & & 0.4 & 112.5 & 60.9 & $17 \leqq$ & & 14474.4 \\
\hline & 1. & & & & & 8.8 & 13.2 & 80.0 & 80 & 9285 & 987 & 9 & 10 & & 1209.0 & 0.5 & 0.62 & 73.8 & 45.2 & 19 & & 19180.8 \\
\hline & & & & & & 9.9 & 13.5 & 71.0 & 72 & 9930 & & 7.6 & & 1354.5 & 1222.5 & 0.39 & 0.41 & 75.2 & 59.7 & 17404 & & 23265.6 \\
\hline Climber 4 & 1. & 1. & & 1. & & 10.9 & 12.6 & 93.0 & 72 & 11445 & 975 & 13.1 & 13.1 & 1891.5 & 1164.0 & 0.57 & 0.7 & 118.0 & 60.0 & 15717 & & 18825.6 \\
\hline & & & & & & & & & & & & & 9.8 & & 937.5 & 0.2 & 0. & 96.0 & 48.0 & & & 17582.4 \\
\hline Climber & 1. & 1. & 2 & 1. & & 12.8 & 16 & 69.0 & 51 & 7455 & 733 & 8.8 & 8.1 & 1164.0 & 834.0 & 0.36 & 0.57 & 116.4 & 55.7 & 19003 & & 13497.6 \\
\hline & 1. & 1. & 2.9 & 2. & & 12.7 & 13.2 & 85.0 & 81 & 10035 & 973 & 10.8 & 12.3 & 1702.5 & 1344.0 & 0.21 & 0.21 & 77.0 & 64.0 & 17404 & & 13231.2 \\
\hline & 1. & 1. & 3.1 & 2. & & 10.0 & 14.2 & 83.0 & 76 & 9615 & 924 & 10.9 & 9.7 & & 1065.0 & 0.37 & 1.22 & 70.5 & 69.0 & $1642 \varepsilon$ & & 30014.4 \\
\hline Climber 9 & 0.9 & 1.3 & 2.7 & 1. & & 7.7 & 9.9 & 76.0 & 73.0 & 9735 & 9495 & 8.1 & 13.7 & 1381.5 & 1270.5 & 0.22 & 0.19 & 74.7 & 78.9 & 12787 & & 14740.8 \\
\hline
\end{tabular}

BMI, body mass index; PRL, prolactin; $T$, testosterone; PG, progesterone; $E_{2}$, estradiol; $\mathrm{fT}_{3}$, free $\mathrm{T}_{3} ; \mathrm{fT}_{4}$, free $\mathrm{T}_{4}$; $\mathrm{SL}$, sea level; $B C$, base camp. 

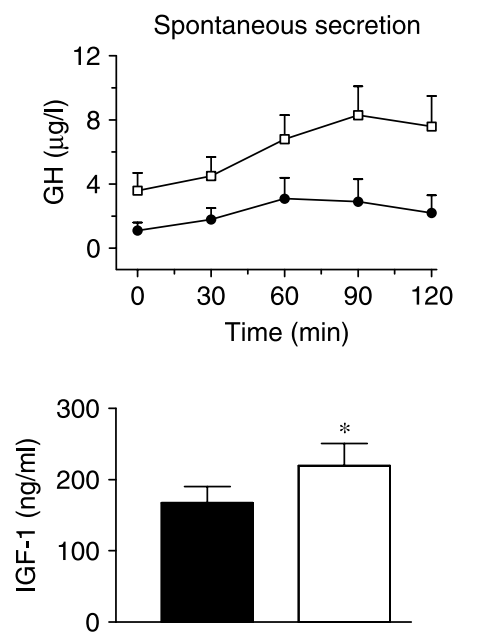

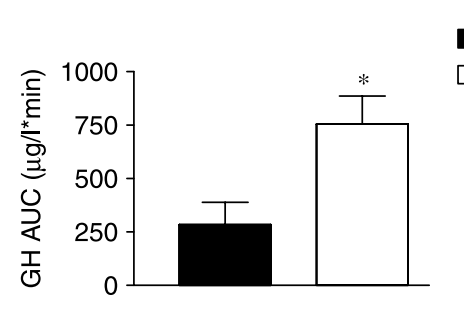

Sea level

Base camp investigate the endocrine and metabolic responses to prolonged exposure to extreme HA hypobaric hypoxia in association with physical exercise such as that performed by elite climbers.

A large variety of factors, including environmental conditions, have been found to influence the hormonal response to exercise at HA $(22,23)$ such as reduced oxygen availability, hypohydration, and alterations in nutritional homeostasis (24-26).

Our present findings are consistent with the adaptations of glucose and lipid metabolism reported to occur during HA exposure, indicating increased dependence on blood glucose as a fuel with a concomitant increase in insulin sensitivity and lipolysis coupled with a decreased reliance on lipid substrate $(2,7,9)$.
This metabolic profile would have also been determined by the remarkable changes in the function of the GH/IGF-I axis. The information about the adaptation, if any, of this axis to extreme HA was scarce. We found that well-trained acclimatized climbers show clear-cut increases in mean GH concentration and this agrees with evidence that physical exercise represents a neuroendocrine-mediated stimulus of somatotropic secretion (27) as well as with the enhancement of the $\mathrm{GH}$ response to GH-releasing hormone recorded in subjects chronically living at HA (28). Again, it had been also reported that low-altitude natives adapted to HA show a more marked GH increase than non-acclimatized subjects (29).

The most intriguing aspect is, however, that the increased GH secretion was coupled with an increase in
Figure 1 Mean ( \pm s.E.M.) GH, IGF-I, and IGFBP-3 levels in nine male elite climbers at sea level and after highaltitude chronic hypoxia exposure $\left({ }^{*} P<0.05\right)$.
Sea level

Base camp
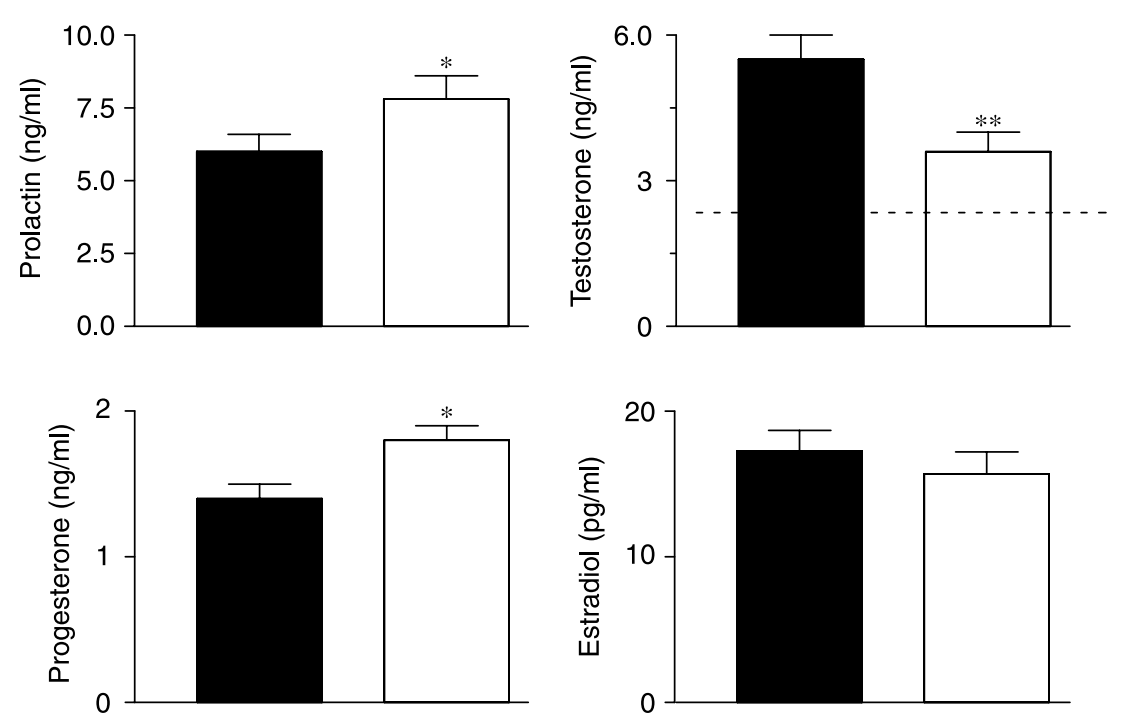

Figure 2 Mean ( \pm S.E.M.) prolactin, testosterone, progesterone, and estradiol levels in nine male elite climbers at sea level and after high-altitude chronic hypoxia exposure $\left({ }^{\star} P<0.05 ;{ }^{\star \star} P<0.01\right.$; dotted line indicates the lower limit of normality in our laboratory). 

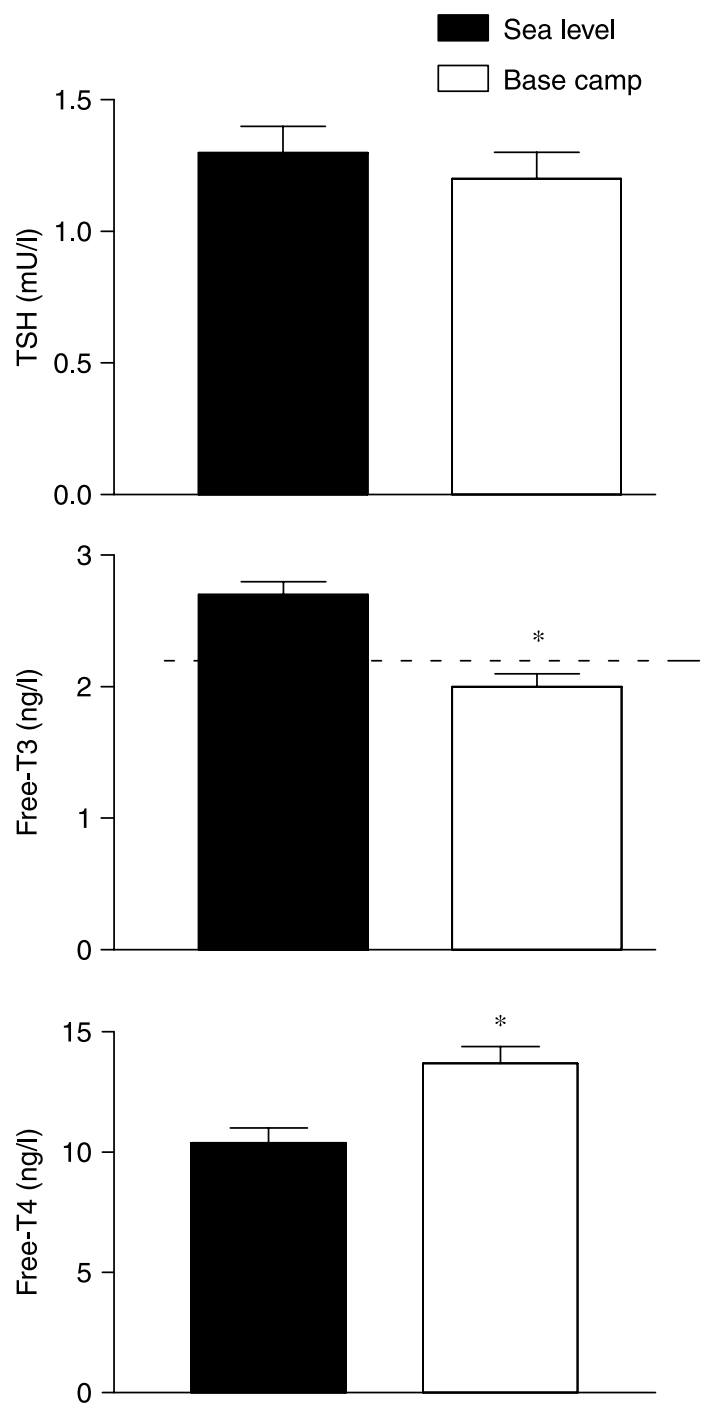

Figure 3 Mean ( \pm S.E.M.) TSH, free T4, and free $T_{3}$ levels in nine male elite climbers at sea level and after high-altitude chronic hypoxia exposure $\left({ }^{\star} P<0.05\right.$; dotted line indicates the lower limit of normality in our laboratory).

either IGF-I or IGFBP-3 levels. Indeed, IGF-I is the best marker of GH status although IGFBP-3, a GH-dependent IGF-I binding protein, also well reflects chronic variations in the status of somatotropic function (30). The clear increase of IGF-I and IGFBP-3 together with the enhancement of mean GH levels therefore clearly points toward increased activity of an anabolic axis like the GH/IGF-I at HA. In fact, increased activity of the GH/IGF-I axis is likely to trigger protein anabolism and might also play a role in the adaptations occurring in glucose and lipid metabolism at HA $(2,7)$.

An adaptive metabolic purpose would also explain the significant increase in lactotropic secretion that followed the exposure to HA in our subjects as well as in another study (16). In fact, prolactin has been shown to markedly affect glucose metabolism (31) but, on the other hand, chronic stressful conditions are known to increase prolactin secretion most likely via neuroendocrine mechanisms (32). Like others (16), we found that significant increase in prolactin levels was coupled with reduction in testosterone levels; in agreement with some previous data, this would likely indicate stress-induced depression in the function of the gonadal axis that, in turn, would be negatively affected by prolactin increase (33). Testosterone decrease in climbers at HA would, however, simply reflect the combined negative influence of hypoxia and strenuous physical exercise; in fact, reduced testosterone levels have been recorded in men in hypoxic conditions of any physical exercise $(16,34,35)$ as well as in subjects undergoing endurance training (36). Moreover, the fact that the GH/IGF-I axis is activated while testosterone is decreased may explain the lack of anabolism and the increased dependence on glucose utilization.

The hypothesis that the athletes were particularly stressed seems contradicted by the lack of any significant change in cortisol and ACTH as well as DHEAS levels. The single basal evaluation of these variables is, on the other hand, not enough to adequately investigate the hypothalamus-pituitaryadrenal axis function and therefore to exclude some stress-induced derangement. In this context, however, it is noteworthy that our findings confirm significant HA-induced elevation in progesterone levels (15). The role of progesterone as a potent respiratory stimulant in the physiological regulation of breathing has been recently emphasized (37); in fact, it has been demonstrated that progesterone is able to increase sensitivity of the respiratory center to $\mathrm{CO}_{2}(37,38)$. Thus, the increase of progesterone levels in hypoxic conditions at HA could be viewed as a stimulus for the respiratory drive; this would be favored by the decline in testosterone levels that are known to exert reduced down-regulation of progesterone receptors (37).

The effects of HA, hypoxia, and physical exercise on the thyroid axis have been more extensively studied (12-14, 39). Although physical exercise per se is not considered as having a significant influence on thyroid function (39), environmental conditions have been reported to play a relevant role. A previous study in subjects who had a short-term stay at extreme HA during Mt. Everest climbing (14) reported an increase in total $\mathrm{T}_{4}$ and $\mathrm{T}_{3}$ concentration associated with an increase in TSH levels. On the other hand, significant elevation of free $\mathrm{T}_{4}$ levels after 3 weeks at $4300 \mathrm{~m}$ without any change in TSH levels have been reported (20). Our present findings recorded after a 2-month stay at HA confirm the lack of change in TSH levels as well as the increase in $\mathrm{fT}_{4}$ levels, while they show significant reduction of $\mathrm{fT}_{3}$ levels that were below the lowest limit of the normal range. This picture suggests an HA-induced low $\mathrm{T}_{3}$ syndrome that would reflect an impairment of peripheral $\mathrm{fT}_{4}$ to free $\mathrm{T}_{3}$ conversion under chronic exposure to HA hypoxia. Indeed, it is reasonable that prolonged exposure to hypobaric hypoxia at extreme HA induces a low $\mathrm{T}_{3}$ syndrome that would also be 
Spontaneous secretion
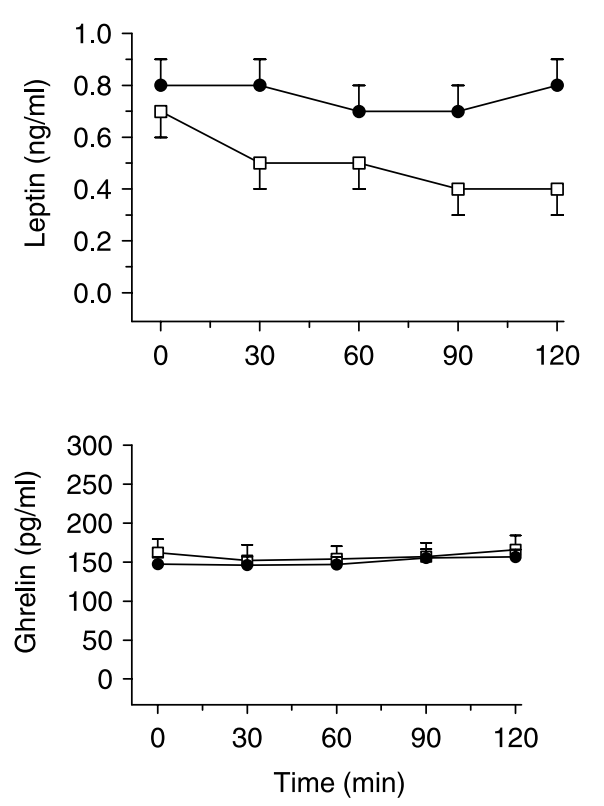

Sea level

Base camp
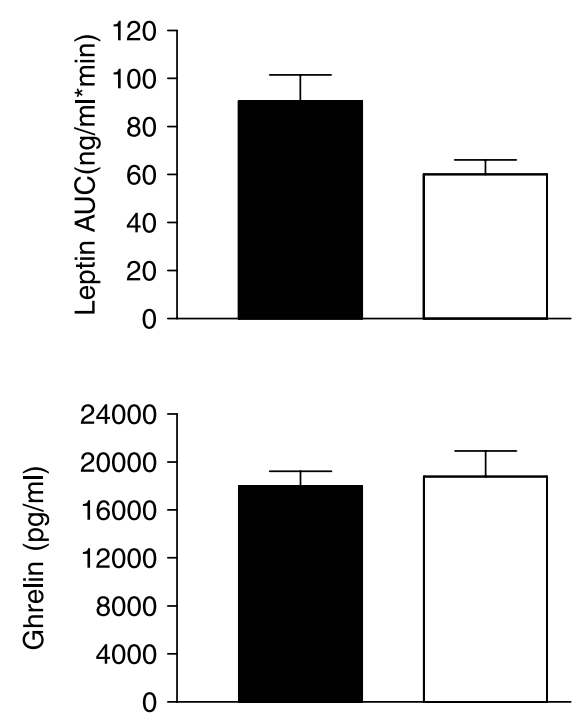

Figure 4 Mean ( \pm s.E.M.) leptin and ghrelin secretion in nine male elite climbers at sea level and after highaltitude chronic hypoxia exposure. explained by the status of negative energy balance caused by strenuous physical exercise (39). The negative energy balance is shown by the clear decrease in body weight that was recorded in our study as well as in other studies in subjects at HA $(10,11)$.

Despite the expected decrease in body weight reflecting the negative energy balance, we did not record any significant variation in either leptin or ghrelin secretion. That either leptin, an adipocyte hormone, or ghrelin, a gastric hormone, play a major role in the regulation of energy balance, appetite, and food intake as well as in peripheral metabolism has been well demonstrated (40). Particularly, decrease in body weight is generally associated with leptin decrease and ghrelin increase, while the opposite picture is associated with body weight excess (40).

Since the loss of fat mass and fat-free mass occurring during a climb to and/or a stay at HA mainly reflects the inability to maintain energy balance $(10,11)$, alterations in leptin and ghrelin secretion at HA had been hypothesized. An increase in leptin coupled with ghrelin decrease has been described after acute exposure to HA $(17,19)$, but other authors reported that prolonged HA exposure is associated with a reduction of leptin concentrations, likely due to the loss of body mass and the strong hypoxia-related sympathetic activation (18). These studies relied on single leptin and ghrelin measurements while we evaluated mean leptin and ghrelin concentrations over $2 \mathrm{~h}$. Indeed, we found a nonsignificant trend toward decreased leptin levels, but ghrelin levels were completely unchanged despite the significant body weight loss. Thus, extreme HA and strenuous physical exercise do not allow the normal physiological response of leptin and ghrelin to significantly decrease body weight and cause negative energy balance.

The mechanism(s) underlying this lack of leptin and ghrelin responses are, at present, unknown. Evidence that ghrelin secretion was not coupled with the clear increase in GH and IGF-I secretion is relevant considering that ghrelin has been discovered as a natural $\mathrm{GH}$ secretagogue and is supposed to play a major role in the positive control of somatotropic function (40). However, more recent studies questioned the physiological importance of ghrelin in the control of GH secretion (40) and our present results in elite climbers agree with these latter studies indicating that the HA-induced enhancement in the activity of GH/IGFI axis was not mediated by ghrelin.

In conclusion, the results of the present study in a unique experimental human model demonstrate that extreme HA and strenuous physical exercise are coupled with peculiar endocrine adaptations. Particularly, these include hyperactivity of the GH/IGF-I axis and a low $\mathrm{T}_{3}$ syndrome but no significant change in ghrelin and leptin as was likely to be expected, also taking into account body weight decrease. These findings would contribute to better understanding human endocrine and metabolic physiology in hypoxic conditions.

\section{Acknowledgements}

Novo Nordisk and IMONT are acknowledged for the financial support of the study. Moreover, the authors wish to thank all the climbers of the expedition, Da 
Polenza A, Mandler R, Santoro S, Tagliabue G, Zatelli C, and Degli Uberti E. The skillful assistance of Bertagna A, Taliano M, Barberis A, Fortunati N, Pagotto U, Brossa C is also acknowledged.

\section{References}

1 Michiels C. Physiological and pathological responses to hypoxia. American Journal of Pathology $2004 \mathbf{1 6 4} 1875-1882$.

2 Brooks GA. Increased glucose dependency in circulatory compensated hypoxia. In Hypoxia and Mountain Medicine, pp 213-216. Eds JR Sutton, CS Houston \& G Coates, Burlington, VA: Queen City Printers, 1992.

3 Young AJ \& Reeves JT. Human acclimatization to high terrestrial altitude. In Textbook of Military Medicine: Medical Aspects of Harsh Enviroments - Volume 2, pp 644-688. Ed. DE Lounsbury, Falls Curch, VA: Office of the Surgeon General, United States Army, 2002.

4 Hansen J \& Sander M. Sympathetic neural overactivity in healthy humans after prolonged exposure to hypobaric hypoxia. Journal of Physiology $2003 \mathbf{5 4 6}$ 921-929.

5 Mazzeo RS \& Reeves JT. Adrenergic contribution during acclimatization to high altitude: perspectives from Pikes Peak. Exercise and Sport Sciences Reviews 200331 13-18.

6 Roberts AC, Reeves JT, Butterfield GE, Mazzeo RS, Sutton JR, Wolfel EE \& Brooks GA. Altitude and beta-blockade augment glucose utilization during submaximal exercise. Journal of Applied Physiology $199680605-615$.

7 Roberts AC, Butterfield GE, Cymerman A, Reeves JT, Wolfel EE \& Brooks GA. Acclimatization to 4300-m altitude decreases reliance on fat as a substrate. Journal of Applied Physiology 199681 1762-1771.

8 Larsen JJ, Hansen JM, Olsen NV, Galbo H \& Dela F. The effect of altitude hypoxia on glucose homeostasis in men. Journal of Physiology 1997504 241-249.

9 Braun B, Rock PB, Zamudio S, Wolfel GE, Mazzeo RS, Muza SR, Fulco CS, Moore LG \& Butterfield GE. Women at altitude: short-term exposure to hypoxia and/or alpha(1)-adrenergic blockade reduces insulin sensitivity. Journal of Applied Physiology 200191 623-631.

10 Westerterp KR \& Kayser B. Body mass regulation at altitude. European Journal of Gastroenterology \& Hepatology 200618 1-3.

11 Hamad N \& Travis SP. Weight loss at high altitude: pathophysiology and practical implications. European Journal of Gastroenterology and Hepatology 200618 5-10.

12 Sawhney RC \& Malhotra AS. Thyroid function in sojourners and acclimatised low landers at high altitude in man. Hormone and Metabolic Research 199123 81-84.

13 Basu M, Pal K, Malhotra AS, Prasad R \& Sawhney RC. Free and total thyroid hormones in humans at extreme altitude. International Journal of Biometeorology 199539 17-21.

14 Mordes JP, Blume FD, Boyer S, Zheng MR \& Braverman LE. Highaltitude pituitary-thyroid dysfunction on Mount Everest. New England Journal of Medicine $1983 \mathbf{3 0 8} 1135-1138$.

15 Basu M, Pal K, Prasad R, Malhotra AS, Rao KS \& Sawhney RC. Pituitary, gonadal and adrenal hormones after prolonged residence at extreme altitude in man. International Journal of Andrology 199720 153-158.

16 Sawhney RC, Chhabra PC, Malhotra AS, Singh T, Riar SS \& Rai RM. Hormone profiles at high altitude in man. Andrologia 198517 178-184.

17 Tschop M, Strasburger CJ, Hartmann G, Biollaz J \& Bartsch P. Raised leptin concentrations at high altitude associated with loss of appetite. Lancet 1998352 1119-1120.

18 Zaccaria M, Ermolao A, Bonvicini P, Travain G \& Varnier M. Decreased serum leptin levels during prolonged high altitude exposure. European Journal of Applied Physiology 200492 249-253.

19 Shukla V, Singh SN, Vats P, Singh VK, Singh SB \& Banerjee PK. Ghrelin and leptin levels of sojourners and acclimatized lowlanders at high altitude. Nutritional Neuroscience 20058 161-165.

20 Barnholt KE, Hoffman AR, Rock PB, Muza SR, Fulco CS, Braun B, Holloway L, Mazzeo RS, Cymerman A \& Friedlander AL. Endocrine responses to acute and chronic high-altitude exposure (4300 meters): modulating effects of caloric restriction. American Journal of Physiology: Endocrinology and Metabolism 2006290 E1078-E1088.

21 Poretti G, Mandler R \& Lipizer M. L'altezza del Monte Everest. 2004 http://www.sogestgeo.it/Ev\%20elevation\%5CEv\%20elevation.htm.

22 Galbo H. Hormonal and Metabolic Adaptation to Exercise New York: Georg Thieme Verlag, 1983.

23 Wade CE. Hormonal regulation of fluid homeostasis during and following exercise. In Contemporary Endocrinology: Sports Endocrinology, pp 207-225. Eds MP Warren \& NW Constantini, Totowa, NJ: Humana Press Inc., 2000.

24 Rose MS, Houston CS, Fulco CS, Coates G, Sutton JR \& Cymerman A. Operation Everest II: nutrition and body composition. Journal of Applied Physiology 198865 2545-2551.

25 Tenney SM \& Jones RM. Water balance and lung fluids in rats at high altitude. Respiration Physiology 199287 397-406.

26 Bert P. La Pression Barometrique, Recherches de Physiologie Esperimentale. Paris: Centre National de la Recherche Scientifique, 1979.

27 Cumming DC. Hormones and athletic performance. In Endocrinology and Metabolism, edn 3, pp 1837-1885. Eds P Felig, JD Baxter \& LA Frohman, New York: McGraw-Hill, 1995.

28 Ramirez G, Herrera R, Pineda D, Bittle PA, Rabb HA \& Bercu BB. The effects of high altitude on hypothalamic-pituitary secretory dynamics in men. Clinical Endocrinology 1995 43 11-18.

29 Heat D \& Williams DR. Endocrine Function in Man at High Altitude. edn 2. pp 247-258. London: Churchill Livingston, 1981.

30 Thissen JP, Ketelslegers JM \& Underwood LE. Nutritional regulation of the insulin-like growth factors. Endocrine Reviews 199415 80-101.

31 Freemark M, Avril I, Fleenor D, Driscoll P, Petro A, Opara E, Kendall W, Oden J, Bridges S, Binart N, Breant B \& Kelly PA. Targeted deletion of the PRL receptor: effects on islet development, insulin production, and glucose tolerance. Endocrinology 2002 $1431378-1385$.

32 Reis FM, Ribeiro-de-Oliveira JA, Machado LJ, Guerra RM, Reis AM \& Coimbra CC. Plasma prolactin and glucose alterations induced by surgical stress: a single or dual response? Experimental Physiology 199883 1-10.

33 De Rosa M, Zarrilli S, Di Sarno A, Milano N, Gaccione M, Boggia B, Lombardi G \& Colao A. Hyperprolactinemia in men: clinical and biochemical features and response to treatment. Endocrine 2003 20 75-82.

34 Semple PD, Beastall GH, Watson WS \& Hume R. Serum testosterone depression associated with hypoxia in respiratory failure. Clinical Science $1980 \mathbf{5 8}$ 105-106.

35 Guerra-Garcia R. Testosterone metabolism in man exposed to high altitude. Acta Endocrinologica Panamericana 19712 55-59.

36 Hackney AC, Moore AW \& Brownlee KK. Testosterone and endurance exercise: development of the 'exercise-hypogonadal male condition'. Acta Physiologica Hungarica 200592 121-137.

37 Saaresranta T \& Polo O. Hormones and breathing. Chest 2002 122 2165-2182.

38 Regensteiner JG, Woodard WD, Hagerman DD, Weil JV, Pickett CK, Bender PR \& Moore LG. Combined effects of female hormones and metabolic rate on ventilatory drives in women. Journal of Applied Physiology 198966 808-813.

39 Bernet VJ \& Wartofsky L. Thyroid function and exercise. In Contemporary Endocrinology: Sports Endocrinology, pp 97-118. Eds MP Warren \& NW Constantini, Totowa, NJ: Humana Press Inc., 2000.

40 Broglio F, Prodam F, Riganti F, Muccioli G \& Ghigo E. Ghrelin: from somatotrope secretion to new perspectives in the regulation of peripheral metabolic functions. Frontiers of Hormone Research $200635102-114$.

Received 6 September 2007

Accepted 2 October 2007 